\title{
Prevalencia de los Virus de Hepatitis en las Hepatitis Agudas en Niños
}

\author{
Dr. José Zacarías S. 1 , Dr. Jorge Rakcla S. ${ }^{2}$, Dra. Marta Velasco R. ${ }^{3}$ y \\ Dr. Patricio Brinck M. ${ }^{1}$ \\ Prevalence of A,B, non Anon B Virusses \\ in Children with Acute Viral Hepatitis
}

\begin{abstract}
We studied 185 children with acutc icteric hepatitis at the Luis Calvo Mackenna Liver Disease Unit refered by the neighborhood outpatient clinic during a 5 year period (1977. 1982).

144 (78\%) of the 185 paticnts with acute hepatitis developed anti - HAV positivity by I.A.H.A. or RIA. Thìty seven patients $(20 \%)$ showed not evidence of acute HAV nor HBV infection and were diagnosed as non A non B hepatitis. Only in 4 patients, markers of hepatitis $B$ virus were found.

Thirty children had an active disease for a period longer than 2 montlss, $36 \%$ of these patients had a non $A$ non $B$ hepatitis and $11 \%$ had Hepatitis $A$.

In eight paticnts with acute fulminant hepatitis we found that $5 \mathrm{had}$ and HAV infections and 3 a non $A$ non $B$ virus infections.
\end{abstract}

El aislamiento de los virus de hepatitis A y B y el desarrollo de técnicas de laboratorio que permiten identificar la participación de estos agentes en las hepatitis aguda ha significado un gran avance en el estudio de las hepatitis ${ }^{1-2-3-4}$. Estudios anteriores realizados en nuestro país han demostrado la baja incidencia del virus de hepatitis $\mathbf{B}$ (H.B.) en la población normal de adultos y niños. Las características epideniologicas y clínicas de las hepatitis en la población infantil chilena sugerian como agente viral más probable el virus de Hepatitis A (H.A. $)^{5}$. Este hecho fue corroborado en investigaciones realizadas en niños normales del Area Oriente de Santiago en las cuales se demostró un porcentaje alto de niños con anticuerpos de hepatitis A a partir de los 2 años de edad ${ }^{6}$.

El objetivo de este trabajo es determinar la participación de los virus de hepatítis en niños con hepatitis aguda.

\section{MATERIAL Y METODO}

Se estudiaron 185 niffos con hepatitis aguda, que consultaron en el Departamento de Hepatología del Hospital Luis Calyo Mackenna o en el Consultorio privado de uno de los autores. El diagnóstico de hepatítis aguda se confirmó con las alteraciones clínicas y de laboratorio.

En una primera etapa se estudiaron 73 niños que consultaron entre Abril 1977 y Diciembre 1978, por hepatitis aguda. Las muestras de sangre fueron procesadas en el Laboratorio de Hepatítis

\footnotetext{
I Servicio Pediatría Hospital "Luis Caivo Mackenna"

2 Universidad de California del Sur, U.S.A.

3 Hospital Salvador.
}

del Hospital John Wensley de Los Angeles, USA. Se utilizó la técnica de Hemoaglutinación por inmunoadherencia para la pesquisa de los anticuerpos de H.A. ${ }^{7}$. Los antigenos y anticuerpos de virus $B$ se investigaron con la técnica de radioinmunoensayo ${ }^{8-9}$. En el resto de los pacientes que consultaron entre Enero 1979 y Diciembre 1981 se utilizó la técnica de radioinmunoensayo en la determinación de anticuerpos de H.A. Esta segunda parte de la investigación fue realizada en el Laboratorio de Hepatología del Hospital Salvador.

\section{RESULTADOS}

En la Tabla 1 se observa que de los 185 niños con hepatitis aguda, en 144 ( $78 \%$ ) se identificó a el Virus de Hepatitis A como agente causal. Sólo se comprobó la participación del Virus $B$ en cuatro ( $2 \%)$ de estos pacientes, dos de los cuales habían recibido transfusiones de sangre entre $2-3$ meses antes de enfermar. En los 37 niños $(20 \%)$ restantes no se comprobó la participación del Virus A ni del $B$, por lo que probablemente corresponden a uno de los virus no A no B. Debemos dejar establecido, que no se investigó la presencia de los virus de Ebstein-Barr, del citomegalovirus ni del virus herpes simple, por no disponer de los recursos técnicos necesarios.

Treinta pacientes prolongaton su enfermedad por un periodo mayor de 2 meses con síntomas clínicos o Transaminasas glutámica pirúvica con niveles sobre 4 veces el valor nornal. En la Tabla 2 se observa que el $11 \%$ de los niños con hepatitis por virus $\boldsymbol{A}$, presentaron una evolución prolongada a diferencia del $36 \%$ de los pacientes con virus no A no B. Los 4 pacientes con hepatitis por virus $B$ mejoraron antes de los 2 meses de evolución. 
Tabla 1.

Hepatitis Aguda en Niños

Estudio de Marcadores Virales $1977-1982$

\begin{tabular}{|c|c|c|c|}
\hline $\begin{array}{l}\text { EDAD } \\
\text { (años) }\end{array}$ & HAV & HBV & $n A_{n} B$ \\
\hline 1 & 1 & - & 5 \\
\hline $1-2$ & 7 & - & 2 \\
\hline $3-5$ & 45 & 1 & 8 \\
\hline $6-8$ & 48 & 1 & 8 \\
\hline $9-16$ & 43 & 2 & 14 \\
\hline Total: 185 & $144(78 \%)$ & $4(2 \%)$ & $37(20 \%)$ \\
\hline
\end{tabular}

Tabla 2.

Estudio de Marcadores Virales en 20 Niños con Hepatitis de Evolución Prolongada $(>2$ meses $)$

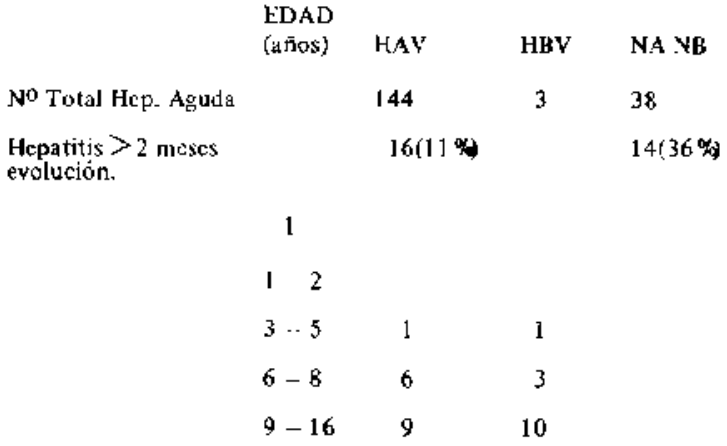

En relación a la edad de los niños estudiados en esta ocasión se apreció un desplazamiento de la curva de incidencia de hepatitis en niños mayores de 9 años, que alcanza a un 30\% en este grupo, cifra que es muy superior a la encontrada por los autores en la investigación anterior.

De los 16 pacientes con H.A. que prolongaron su enfermedad por un período superior a 2 meses, el $56 \%$ de ellos eran niños con edad superior a los 9 años. Este porcentaje fue superior en los niños con hepatitis por virus no $A$ no $B$ (nAnB) donde el $71 \%$ de ellos eran mayores de 9 años.

Desde 1977 hasta 1983, hemos logrado estudiar marcadores virales en 8 pacientes con hepatitis fulminante de los cuales fallecieron 3 . En la Tabla 3 se observa que de los 3 casos de hepatitis no A no B fallecieron 2 a diferencia de 1 de los 5 pacientes con hepatitis por virus $A$.

\section{COMENTARIO}

Las nuevas técnicas de rađioinmunoensayo utilizadas actualmente en el diagnóstico etiológico de las hepatitis han facilitado un mejor conocimiento
Tabla 3.

Estudio de Matcadores de Hepatitis en 8 Niños con Hepatitis Fulminante - 1977-1983
Tipo de Virus

Virus A

Virus $\mathrm{B}$

Virus no $A$ no $B$

$$
\text { No Casos }
$$$$
5
$$$$
3
$$

Fallecidos de la epidemiologia y de la patogenia de las hepatitis, permitiendo además hasta cierto punto determinar el pronóstico de la enfermedad. Investigaciones de los últimos affos han demostrado que el virus de $\mathbf{H}$.A. no es causante de hepatitis crónica, a diferencia de los virus nAnB y virus $B$. La confirmación de la participación del virus $A$ como agente causal en un paciente con hepatitis aguda permite adelantar un buen pronóstico en relación a que no seguirá un curso crónico. Por lo tanto en aquel paciente con hepatitis aguda por virus $A$ que siga un curso prolongado no se justifica realizar una biopsia hepática como se sugería hasta hace algunos af́os con el propósito de descartar una enfermedad crónica.

Los anticuerpos de H.A. tipo lgM que permiten confirmar la participación del virus A aparecen al inicio de los primeros síntomas y desaparecen entre las 8 y 12 semanas de evolución ${ }^{10}$. Por lo tanto existe una limitación de esta técnica y es que debe emplearse antes de las 12 semanas de enfermedad. La presencia de anticuerpos de H.A. tjpo IgG sólo indica infección antigua por virus de H.A. La técnjca de hemoaglutinación por inmunoadherencia exige la toma de dos muestras una al inicio de la enfermedad y la segunda a las 8 semanas de evolución; con este examen se pretende comprobar una sero conversión de los títulos de anticuerpos de H.A., tipo IgG, hecho que confirma la participación del virus $\mathbf{A}$.

En esta investigación ha quedado demostrado que en nuestro medio la hepatitis por Virus A es, como era de esperar, significativamente más frecuente que otros tipos de hepatitis. Situación explicable por las precarias condiciones sanitarias de la población. Es interesante además los resultados que demuestran la importante participación de los virus $\mathrm{nAnB}$ en la etiologia de las hepatitis agudas en nifios, situación semejante a la descrita por el Dr. Villarejos en Puerto Rico ${ }^{1}$. Es probable que en este grupo de pacientes y especialmente en los menores de 1 año, hayan participado, en aiguno de ellos, otros virus causantes de hepatitis que no fueron investigados. Aquí se confirman una vez más que el virus $B$ tiene un rol poco importante en las hepatitis agudas en niños, hecho ya establecido en otras publicaciones nacionales ${ }^{12-13}$. 
La importante medida de implementar los Bancos de Sangre con las técnicas necesarias para pesquisar el virus de H.B., permitirá disminuir más aún la participación de este agente en las hepatitis post transfusionales. No existen métodos diagnós. tico para determinar la presencja de los virus no $A$ no B y estos siguen ocupando el primer lugar en las hepatitis post transfusionales ${ }^{14}$.

En to que concierne al tiempo de evolución se observó que tanto en los niños con hepatitis por virus A como por Virus nAnB pueden seguir con signos de actividad por un período más allá de 2 meses; situación que es significativamente más frecuente con los virus nAnB.

El aumento de la incidencia de hepatitis aguda en niños mayores de 9 años observada en este estudio probablemente se deba a que aquí se incluyeron algunos pacientes con hepatitis aguda de un medio socio-económico alto, atendido por uno de los autores en Consultorio privado. Otro factor importante que pueda explicar este hecho, son las mejores condiciones sanitarias de las nuevas poblaciones marginales del Area Oriente de Santiago.

En relación a hepatitis fulminante, sólo se han logrado investigar 8 pacientes, por to que a pesar de que se observa una mayor mortalidad en las hepatitis por virus no $A$ no $B$, no podemos ser concluyente al respecto.

\section{RESUMEN}

El aislamiento de los Virus A y B permitió el desarrallo de nuevas técnicas de laboratorio que han hecho posible su jdentificación en pacientes con Hepatitis aguda.

Se estudiaron 185 niños con hepatitis aguda atendjdos en el Departamento de Hepatología del Hospital Luis Calvo Mackenna, o en la consulta privada de uno de los autores de este trabajo, entre los años 1977-1982.

En la investigación de los marcadores de hepatitis se utilizó la técnica de Hemoaglutinación por Inmuno adherencia y radioinmuno ensayo.

En el $78 \%$ de los niños se comprobó la participación del Virus A como agente causal de la hepatitis aguda y sólo en el $2 \%$ se identificó el virus B. En el $20 \%$ restante corresponde a hepatitis probablemente causadas por los Virus no A no B.
En 30 niños se observó una evolución por un periodo superior a los 2 meses, $36 \%$ de ellos tenían una hepatitis por Virus no A no B y el $10 \%$ hepatitis por Virus $A$.

Ocho pacientes presentaron una hepatitis aguda fulminante, 5 de los cuales fueron hepatitis A y 3 no A no $B$.

\section{BIBLIOGRAFIA}

1 Blumberg, B.S., Aiter, H.J., Visnich, S.: "A New antigen in leukemia sern. Jama. 191: 541, 1965.

2 Blumberg, B.S., Sutnick, A.I., London, W.T.: Autralian antigen as a hepatitis virus, variation in host response. Am. J. Med. 48:1,1970.

3 Feinstone, S.M., Kapikizn, A.Z., Purcell, R.H.: Hepatiijs A.: Detection by immune electron microscopy of a virus like antigen associated with acute iliness. Science 182: 1026.1973 .

4 Dienstag, J.Z., Feinstone, S.M., Kapikian, A.Z. ahd Purcell, R.H.: Faecal Shedding of Hepatitis A antigen. The Lancet 1: $765,1975$.

5 Zacarias, J., Rakela, J., Macho, L., Mostey, J.. Estudio de anticuerpos de Hepatitis A en riños. Bol Med. Hospital Intantil de México. 36: 571, 1979.

6 Zacarias, J., Soria, M., y Negron, A.: Aspectos epidemiológicos, clínico $y$ de laboratorio de las Hepatitis Viral. Rev. Chil. de Pediat. 39: 610, 1968.

${ }^{7}$ Hilleman. M.R., Provost, P.J., Miller, W.J., Villarejos, V.M., Sttensohn. O.L, M. Caleer, W.: Development and utilization of complement - fixation and immune adherence test for human hepatitis $A$ virus and antrbody. Am. J. Med. Sci. 270: 93, 1975.

${ }^{3}$ Bradley, D.W., Maynard, J.E., Hindman, S.H. et al.: Sera diagnosis of viral hepatitis A.: detection of acute phase inmunoglobulin $M$ anti hepatitis $A$ virus by radiounmuno assay. J. Clin. Microbiol. 5: 521, 1977.

9 Ling, C.M., Overfy, L.R.: Prevalence of Hepatitis B virus antigen as revealed by fürect radioimmunoassay with $125 \mathrm{I}$. - antibody. J. Inmunolgy. 109: 834, 1972.

10 Storch, G.A., Bodicky. C., Parker, M., Blecka, L.J. and $A A C H$, R.D.: Use of Conventional and IgM - Specific Radioimmunoassays for Anti-Hepatitis A Antibody in an Outbreak of Hepatitis A. Am. J. Med. 73: 663, 1982.

11 Vilharejos, V.M., Visona, K.A., Duarte, C.A. ef al.: Evidence of viral hepatitis other than type $A$ or $B$ among persons in Costa Rica. N. Engl. J. Med. 293: $1350,1975$.

12 Velasco, K. $y$ Katz, R.i Antigeno Australiano en mucstras de población chilena y en diversos cuadros patológicos. Rev. Med. Chile, 98: 1, 1970.

13 Gutierrez, C., Aviles, C., Welch, E. Ceresa, S. y Guerrero, $X$.: Hepatitis por virus $B$ en la infancia. Rey. Chil. de Pediat. 52: 128, 1981

14 Alter, H.J., Holland, P.V., Purcell, R.H. and Popper, $H$.: Transmissible agente in non A non B Hepatitis. The Lancet, 1: 459, 1978. 